\title{
EFEKTIVITAS PENERTIBAN PEDAGANG KREATIF LAPANGAN OLEH SATUAN POLISI PAMONG PRAJA DI JALAN JAWA KOTA PALANGKA RAYA
}

\author{
Effectiveness of regulating creative trader field by the police unit \\ of Pamong Praja in Jalan Jawa city Palangka Raya
}

\section{Fatchurahman*}

Sofiah

Universitas Muhammadiyah Palangkaraya, Palangka Raya, Central Kalimantan, Indonesia

email:

fatchurahman@umpalangkaraya.ac.id

\section{Kata Kunci:}

Efektivitas

Penertiban

Pedagang Kreatif Lapangan

\section{Keywords:}

Effectiveness

Policing

Creative Merchant Field

\section{Accepted}

January 2019

\section{Published}

April 2019

\begin{abstract}
Abstrak
Penelitian ini bertujuan untuk mengkaji dan menganalisis Efektivitas Penertiban Pedagang Kreatif Lapangan Oleh Satuan Polisi Pamong Praja di Jalan Jawa Kota Palangka Raya. Penelitian ini menggunakan metode penelitian kualitatif. Sumber data berasal dari organisasi satuan polisi pamong praja kota palangka Raya, PKL, masyarakat di pasar besar jalan jawa kota Palangka Raya, serta dokumendokumen yang mendukung penelitian ini. Teknik pengumpulan data dengan cara observasi, wawancara, dokumentasi. Teknik analisis data meliputi data reduction, data display dan counclusion drawing Verification.

Berdasarkan hasil penelitian ini, dapat diketahui bahwa Penertiban Pedagang Kreatif Lapangan (PKL) dilakukan karena banyaknya pedagang kreatif diperkotaan yang memanfaatkan tempat umum dalam kegiatan perdagangan sehingga dilakukkan penertiban oleh Satpol PP. serta efektivitas penertiban serta faktor pendukung dan penghambat penertiban pedagang kreatif lapangan oleh Satpol PP di Jalan Jawa Kota Palangka Raya yaitu sarana prasarana yang kurang memadai untuk melakukkan penertiban seperti alat transfortasi yang sudah terlalu tua untuk melakukkan kegiatan patroli serta minimnya anggaran dana yang didapat.
\end{abstract}

\begin{abstract}
This research aims to examine and analyze the effectiveness of creative traders in the field by the police unit of Pamong Praja at Jalan Jawa City Palangka Raya. This research uses qualitative research methods. The source of the data is derived from the Police unit organization of the city Palangka Raya, PKL, the community in the large market of the street Java City Palangka Raya Raya, as well as documents that support this research. Data collection techniques by observation, interviews, documentation. Data analysis techniques include data reduction, data display and conclusion drawing Verification.

Based on the results of this study, it is known that the use of Creative Trader Field (PKL) is done because of the number of creative traders who have been made use of public places in the trading activities so that the implementation by Satpol PP. As well as the effectiveness of regulating and supporting factors and the implementation of creative traders field by Satpol PP on Jalan Java City Palangka Raya is insufficient infrastructure to perform regulation such as transportation tools that is too old to carry out patrol activities and the lack of budget earned funds.
\end{abstract}

\section{PENDAHULUAN}

Dalam pelaksanaan pembangunan memerlukan banyak unsur-unsur yang dapat menunjang baik itu dari segi mental, maupun dana yang diperlukan bagi pembangunan itu sendiri. Dan juga terkait dengan ketertiban umum menjadi langkah awal dalam mensukseskan pembangunan yang sedang berjalan. Dalam meningkatan pembangunan di daerah salah satunya, keamanan dan ketertiban umum yang mana kedua hal tersebut merupakan salah satu inti dari pembangunan untuk meningkatkan kualitas dan daya saing daerah.

Palangka Raya menjadi sasaran utama para urban untuk mencari lapangan pekerjaan yang berimbas pada bertambahnya jumlah penduduk, serta berubahnya tata ruang kota akibat berdirinya bangunan liar yang tidak berizin dan juga meningkatnya jumlah pedagang kreatif lapangan yang berjualan tidak pada tempat yang telah 
ditentukan. Pedagang kreatif lapangan atau yang sering disebut dengan PKL adalah pedagang yang didalam usahanya mempergunakan sarana dan/atau perlengkapan yang mudah dibongkar pasang, dipindahkan dan/atau mempergunakan tempat usaha yang menempati tanah yang dikuasai Pemerintah Daerah dan/atau pihak lain. Sebelumnya pedagang kreatif lapangan ini adalah pedagang kaki lima yang mana pedagang kaki lima biasa yang sering menjajakan dagangannya di bahu-bahu jalan. Pedagang kreatif lapangan adalah pedagang yang mungkin tarafnya lebih tinggi dari pedagang kaki lima, pedagang yang kreatif baik dalam penyusunan rencana maupun pencapaian targenya.

Kehadiran PKL di daerah perkotaan merupakan realitas sosial yang sering menimbulkan permasalahan pada penataan fisik kota dan juga permasalahan lingkungan. Khususnya di Kota Palangka Raya, hal ini disebabkan lokasi yang digunakan tempat berjualan PKL menyalahi aturan sesuai tata ruang yang telah ditetapkan dan dilarang Pemerintah Daerah dan secara otomatis hal ini menyebabkan kesan kumuh dan akibatnya membuat pemandangan yang tidak sedap.

Ketertiban umum menjadi langkah awal dalam menysukseskan pembangunan yang sedang berjalan. Banyaknya jumlah PKL disekitar pasar besar tepat di jalan Jawa tersebut, membuat sepanjang lokasi berjualan tersebut menjadi ramai dan tidak teratur. Seperti yang telah di terangkan pada peraturan daerah. Peraturan Daerah Kota Palangka Raya Nomor 4 Tahun 2013 tentang Pengaturan, Penertiban dan Pengawasan Pedagang Kreatif Lapangan, atau yang sering dikenal dengan Pedagang Kaki Lima. PKL pada umumnya, melakukan usahanya ditempat atau fasilitas umum. Salah satu tempat yang ramai dan bisa dijadikan menjadi lapak para PKL adalah Pasar tradisional. Pasar tradisional menjadi lahan bagi PKL, karena setiap hari pembeli berbelanja untuk memenuhi kebutuhan seharihari ke pasar. Setiap hari para PKL berjualan di diluar pasar besar dengan menggunakan lapak yang digelar di bahu-bahu jalan ditambah jumlah PKL yang semakin banyak dan menimbulkan ketidakaturan. Hal ini menyebabkan ramainya lalu lintas disepanjang Jalan Jawa dan menjadikan kemacetan disepanjang jalan tersebut. Terkadang para pembeli juga melakukan transaksi jual beli diatas motor dengan alasan karena tidak mau membayar uang retribusi parkir. Banyaknya PKL disekitar pasar tersebut terjadi kemacetan dan jalanan pun juga tidak teratur diakibatkan ramainya penjual dan pembeli yang bergerombol disatu titik yang sama.

Bagaimana juga, PKL yang merupakan bentuk dari sektor informal dapat membantu mengurangi pengangguran yang ada. Serta adanya kebutuhan terhadap PKL oleh masyarakat menjadikan keberadaan para PKL semakin membanyak. Terutama masyarakat yang kelas menengah masih membutuhkan mereka untuk memenuhi kebutuhan yang terjangkau harganya. Disisi lain keberadaan pedagang kreatif lapangan menciptakan kawasan menjadi kumuh, terjadi kemacetan, dan juga mengurangi keindahan tata kota. Untuk mengatasi masalah yang ditimbulkan PKL ini dengan adanya penertiban para PKL tersebut dan dapat mengatasi masalah yang ditimbulkan selama ini, serta juga sebagai bentuk dari menciptakan kota sesuai dengan selogan Kota Palangka Raya, yaitu Kota Cantik. Didalam penelitian ini bertujuan untuk mengetahui secara mendalam, menganalisis, serta menggambarkan efektifitas penertiban pedagang kreatif lapangan oleh satuan polisi pamong praja yang ada di Jalan Jawa Kota Palangka Raya.

Efektivitas berasal dari kata dasar efektif. Menurut Kamus Besar Bahasa Indonesia (2008:375), kata efektif mempunyai arti efek, pengaruh, akibat atau dapat membawa hasil. Sedangkan efektivitas adalah keefektifan. Jadi, efektivitas adalah keaktifan, daya guna, adanya kesesuaian dalam suatu kegiatan orang yang melaksanakan tugas dengan sasaran yang dituju. 
Efektivitas merupakan salah satu pencapaian yang ingin diraih oleh sebuah organisasi.

Menurut Hall (Tangkilisan, 2005:67), efektivitas adalah tingkat sejauh mana suatu organisasi merealisasikan tujuannya, semua konsep tersebut hanya menunjukan pada pencapaian tujuan organisasi. Sedangkan Penertiban menurut Widjajanti, Retno (2000:10) adalah usaha atau kegiatan untuk mengambil tindakan agar pemanfaatan ruang sesuai rencana dapat terwujud.

\section{METODOLOGI}

Dalam hal ini peneliti menggnakan pendekatan Kualitatif. Peneliti ingin mendeskripsikan mengenai penertiban pedagang kaki lima di Kota Palangka Raya. Sebagaimana masih banyak yang berjualan diarea terlarang. Penulis mengkaji setiap peristiwa terjadi dengan maksud agar dapat mengetahui hasil penelitian secara jelas dan rinci suatu data dan fakta sesuai dengan yang terjadi di lapangan. Dengan kata lain laporan penelitian akan berisi kutipan-kutipan data untuk memberi gambaran penyajian laporan tersebut. Adapun yang menjadi informan yaitu para pedagang kreatif lapangan, masyarakat, Ketua RT, ketua PKL dan juga pihak Satpol PP Kota Palangka Raya. Adapun yang menjadi objek penelitian ini adalah Efektivitas Penertiban Pedagang Kreatif Lapangan oleh Satuan Polisi Pamong Praja di Jalan Jawa Kota Palangka Raya.

\section{HASIL DAN PEMBAHASAN}

Pelaksanaan penertiban yang dilakukan Satuan Polisi Pamong Praja Kota Palangka Raya melalui beberapa langkah, yakni :

I. Sosialisasi

Satuan Polisi pamong Praja dalam sebelum melakukan penertiban kepada pedagang kreatif lapangan (PKL) terlebih dahulu Satuan Polisi Pamong Praja melakukan teguran. Sebelum melakukan teguran Satuan Polisi Pamong Praja pertama-tama melakukan sosialisasi kepada masyakarat akan pentingnya ketentraman dan ketertiban umum demi menjaga daerah atau kota agar menjadi nyaman terutama untuk masyarakat yang ada di daerah atau kota tersebut.

2. Maksud dan Tujuan

Bahwa pada pelaksanaannya dimulai dengan para anggota-anggota Satuan Polisi Pamong Praja menyampaikan tujuan dari penertiban, sebagaimana yang diketahui bahwa penertiban itu sendiri merupakan suatu unsur yang mana dalam penertiban tersebut menjadikan suatu daerah atau wilayah itu bebas dari kesan kumuh dengan intinya dilakukannya penertiban ini adalah untuk menjadikan suatu daerah tersebut tentram dan nyaman. Banyaknya Pedagang Kreatif Lapangan (PKL) di pusat perkotaan menimbulkan kemacetan arus lalu lintas dan kerawanan keamanan, kegiatan Pedagang Kreatif Lapangan (PKL) tersebut memanfaatkan tempat umum. Hal ini yang menyebabkan Kota menjadi semerawut, tidak bersih, tidak indah, dan tidak nyaman. Selain itu berpotensi menimbulkan kerawanan sosial, sehingga diperlukan penertiban serta penataan PKL di kawasan perkotaan.

Bahwa Satuan Polisi Pamong Praja sudah menyampaikan tujuan dari penertiban terhadap Pedagang Kreatif Lapangan (PKL), sesuai dengan standar operasional prosedur agar dalam penegakan Peraturan Daerah berjalan sesuai dengan tujuan yang diinginkan. Setelah menyampaikan tujuan dari penertiban tersebut namun masih ada pedagang kreatif lapangan yang tidak mengikuti peraturan Satpol PP akan memberikan sanksi pertama yaitu berupa teguran.

3. Patroli Rutin

Satuan Polisi Pamong Praja dalam menjalankan tugasnya untuk menertibkan pedagang-pedagang yang tidak memiliki izin yang mana pedagang 
tersebut berjualan di area yang tidak diperbolehkan untuk berjualan. Sebelum melakukan teguran Satuan Polisi Pamong Praja melakukan patroli rutin ke tempat-tempat yang rawan, terutama tempat yang banyak PKL.

4. Teguran

Teguran tersebut merupakan teguran yang bertahap, dimulai dengan teguran secara lisan kepada pedagang kreatif lapangan (PKL) itu sendiri, sampai dengan teguran I (satu), 2 (dua) dan 3 (tiga). Setelah itu berlanjut dengan teguran menggunakan surat edaran yang telah dikeluarkan Pemerintah Kota (Walikota), surat tersebut di sebarkan oleh satuan Polisi Pamong Praja kepada para Pedagang Kreatif lapangan (PKL) tersebut. Teguran menggunakan surat tersebut juga dibagikan sama seperti teguran lisan.

Hasil wawancara antara penulis dengan Satuan Polisi Pamong Praja dan juga Pedagang Kreatif Lapangan (PKL), dapat disimpulkan bahwa Satuan Polisi Pamong Praja telah melaksanakan tugasnya untuk memberikan surat teguran kepada para Pedagang Kreatif Lapangan (PKL). Akan tetapi berbeda tanggapan dari para PKLnya itu sendiri mereka berfikir bahwa dengan berjualan dipinggir jalan tersebut mereka lebih mudah mendapatkan pelanggan dibandingkan dengan pedagang yang berada di pertokoan. Disinilah yang menjadikan kejanggalan antara pihak Satpol PP dan juga PKL yang mana tidak dapat bersinergi bekerjasama untuk memperindah perkotaan.

Salah satu tujuan pemerintah kota dalam menertibkan pedagang kreatif lapangan (PKL) adalah untuk menanta daerah atau kota agar menjadi nyaman dan mewujudkan Kota Cantik Palangka Raya, bersih dan aman seperti julukannya. Berdasarkan hasil observasi, Satuan Polisi Pamong Praja dalam melaksanakan tugas pokok dan fungsinya sebagai aparatur Negara yang mana tugasnya adalah untuk menjaga ketentraman dan ketertiban umum bagi masyarakat. Satuan Polisi
Pamong Praja dalam menjalankan tugasnya dengan melalui tahap sosialisasi kemudian memberikan teguran lisan hingga tertulis sampai dengan melakukan tindakan penertiban secara tiba-tiba kepada para Pedagang Kreatif Lapangan (PKL). Dalam melakukan penertiban tersebut para anggota Satuan Polisi Pamong Praja melakukan tindakan seperti mengambil peralatan dan barang dagangan para PKL. Barang dagangan yang disita tersebut dibawa pihak Satpol PP ke Kantor lalu diletakkan di gudang sampai pihak PKL bersangkutan yang barang dagangannya disita itu datang dan mengambil barang tersebut. Ada pula barang dagangan seperti gerobak, atau alat dagang lainnya disita oleh Satpol PP, lalu pihak Satpol PP menyerahkan kepada Pengadilan dan pengandilan tersebut yang melanjutkan dan mengusut kasus tersebut.

Selain itu KTP para Pedagang Kreatif Lapangan (PKL) diambil pihak Satpol PP, KTP para PKL tersebut diambil untuk diproses pihak Satpol PP dan PKL yang KTPnya diambil pihak Satpol PP, supaya mengambilnya ke Kantor Satpol PP dan setelah itu menandatangai surat perjanjian yang mana tujuan dari surat perjanjian tersebut adalah agar PKL tersebut tidak berjanji tidak akan berjualan lagi di tempat tersebut yang mana sebenarnya tempat yang ditempati para PKL tersebut adalah tempat yang tidak diperbolehkan untuk berjualan.

Berdasarkan hasil observasi dan diperkuat dengan pengecekan dan data dokumentasi Standar Operasional Prosedur dan juga Peraturan Daerah (Walikota), yang penulis lakukan dapat diketahui bahwa pada Satuan Polisi Pamong Praja dalam melaksanakan penertiban terhadap Pedagang Kreatif Lapangan bisa dikatakan cukup bagus dalam pencapaian tujuannya akan tetapi keras kepala dari pihak Pedagang Kreatif Lapangannya yang menyulitkan Satpol PP dalam melakukan penertiban.

Dalam pencapaian tujuan penertiban tersebut adanya faktor pendukung dan penghambat dalam pelaksanaan 
penertiban pedagang kreatif lapangan (PKL) oleh Satuan Polisi Pamong Praja Kota Palangka Raya. Setiap kegiatan dalam menjalankan tugas pokok dan fungsi sebagai aparatur Negara tentu saja tidak pernah lepas dari adanya faktor pendukung dan penghambat, begitu pula degan pelaksanaan penertiban pedagang kreatif lapangan (PKL) tidak akan berhasil tanpa adanya hal-hal yang mendukung dalam pelaksanaan penertiban pedagang kreatif lapangan (PKL) itu sendiri yakni :

a. faktor pendukung pelaksanaan penertiban PKL adalah koordinasi yang dilakukan tiap bidangbidang di Satpol PP dalam melakukan tugas pokok dan fungsinya.

b. Faktor Penghambat dalam penertiban yaitu masih minimnya anggaran yang didapat. Selain mengenai anggaran, kendala atau penghambat yang dialami Satuan Polisi Pamong Praja yaitu mengenai sarana dan prasarana yang mana masih bisa dibilang belum cukup memadai untuk melakukan penertiban dan juga dikarenakan alat transportasi yang sudah terlalu tua untuk melakukan operasi patroli setiap harinya.

\section{KESIMPULAN}

Banyaknya Pedagang Kreatif Lapangan (PKL) di pusat perkotaan menimbulkan kemacetan arus lalu lintas dan erawanan keamanan, kegiatan Pedagang Kreatif Lapangan (PKL) tersebut memanfaatkan tempat umum. Pelaksanaan penertiban pedagang kreatif lapangan oleh Satuan Polisi Pamong Praja Kota Palangka Raya. Secara keseluruhan pelaksanaan penertiban pedagang kreatif lapangan (PKL), telah dilakukan dengan baik oleh Satuan Polisi Pamong Praja, mereka menjalankan tugas pokok dan fungsi sesuai dengan standar operasional prosedur yang mereka miliki.

Faktor pendukung dan penghambat penertiban pedagang kreatif lapangan oleh Satpol PP di Jalan Jawa Kota Palangka Raya. Salah satu faktor pendukung berjalannya tugas pokok dan fungsi yang menjadi tanggungjawab para anggota-anggota Satuan Polisi Pamong Praja adalah koordinasi yang baik. Kerjasama antar bidang yang ada di Kantor Satuan Polisi Pamong Praja ini. Kendala atau penghambat yang dialami Satuan Polisi Pamong Praja yaitu anggaran serta mengenai sarana dan prasarana yang mana masih bisa dibilang belum cukup memadai untuk melakukan penertiban dan juga dikarenakan alat transportasi yang sudah terlalu sedikit untuk melakukan operasi penertiban dan patroli setiap harinya.

\section{REFERENSI}

Abdurahmat. 2008. Efektivitas Organisasi: Edisi Pertama. Airlangga. Jakarta.

Arikunto, Suharsimi. 2007. Manajemen Penelitian. PT. Rineka Cipta. Jakarta.

Atun, Umi. 20I5. Penertiban Pedagang Kaki Lima Oleh Satpol PP di Pasar pagi Arengka Kota Pekan Baru. Jom FISIP Volume 2 Nomor I.

Buchari, Alma. 2002. Manajemen dan Pemasaran Jasa. CV. Alfabeta. Bandung.

Ghoni, Djunaidi dan Fauzan Al-Mansur. 2012. Metodologi Penelitian Kualitatif. Ar-Ruzz Media. Yogyakarta.

Harsan Wardani, Ifan. 2017. Studi Tentang Penertiban Pedagang Kaki Lima Oleh Dinas Pasar Di Pasar Segiri Kota Samarinda, ejournal Ilmu Pemerintah. volume 5, Nomor I, I45-I58.

Hendrizal, M. 2012. Peranan Dinas Pengelolaan Pasar Dalam Penertiban Pedagang Kaki Lima (Studi Kasus Pada Simpang Aur Kota Bukit tinggi). Skripsi. Tidak Diterbitkan. Fakultas Ekonomi dan IImu Sosial. Universitas Islam Negeri Sultan Syarif Kasim: Riau.

Indrianti, Weny. 20I4. Perbandingan Kebijakan dan Upaya Pemerintah Dalam Penertiban Pedagang Kaki Lima Antara Kabupaten Berau Dengan Pasar Tanah Abang Jakarta. ejournal IImu Pemerintahan. Volume 2, Nomor 4, 3288-330I. 
Muasaroh, Latifatul. 2010. Aspek-aspek Efektivitas. Literatur Buku. Yogyakarta.

Pasolong, Harbani. 2013. Metode Penelitian Administrasi Publik. Alfabeta. Bandung.

Ririn, Indriastuti. 2012. Efektivitas Organisasional. Ekonomi dan Kewirausahaan. Jom Volume 12 Nomor I.

Sailendra, Annie. 20I5. Langkah-langkah Praktis Membuat SOP. Cetakan Pertama. Trans Idea Publishing. Yogyakarta.

Saputra, Bayu Rholen. 2014. Profil Pedagang Kaki Lima yang Berjualan di Badan (Studi Di Jalan Teratai dan Jalan Seroja Kecamatan Senapelan). Jom Fisip Volume I Nomor 2.

Siagian, Sondang P. 200I. Manajemen Sumber Daya Manusia. Bumi Aksara. Jakarta.

Steers, Richard M. 1985. Efektivitas Organisasi. Erlangga. Jakarta.

Tangkilisan, Hassel Nogi S. 2005. Manajemen Publik. Grasindo. Jakarta.

\section{Perundang-undangan}

Peraturan Daerah Kota Palangka Raya Nomor 13 Tahun 2009 Tentang 67 Pengaturan, Penertiban dan Pengawasan Pedagang Kaki Lima Palangka Raya: Sekretaris Daerah Kota Palangka Raya.

Peraturan Daerah Kota Palangka Raya Nomor 4 Tahun 2013 Tentang Pengaturan, Penertiban dan Pengawasan Pedagang Kreatif Lapangan. Palangka Raya: Sekretaris Daerah Kota Palangka Raya.

Peraturan Menteri Dalam Negeri Republik Indonesia Nomor 54 Tahun 20II Tentang Standar Operasional Prosedur Satuan Polisi Pamong Praja.

Peraturan Pemerintah Republik Indonesia Nomor 16 Tahun 2018 Tentang Satuan Polisi Pamong Praja. Jakarta: Kementerian Sekretariat Negara Republik Indonesia. 